\title{
AGMNOWLEDGMENTS
}

$\mathrm{n}$ the process of bringing this work to a publishable state, I have benefited tremendously from the contributions of many persons-first and foremost, in-depth readings by Jerry Marwell, Jane Piliavin, Jane Collins, Mitch Duneier, and Maria Lepowski. Helpful readers of earlier drafts include Herbert Hill at the University of Wisconsin, Michael Burawoy from the University of California, Heather Hartley (now of Portland State University), Amy Cantoni and Lisa Schreibersdorf at the UW Writing Center, Ronni Tichenor at the SUNY Institute of Technology, Linda Goldenhar (formerly of National Institute of Occupational Safety and Health [NIOSH] and currently at the University of Cincinnati), and Judy Wolf, a writing colleague and friend. Jon Harrington served formally and informally as my personal editor for several versions of the manuscript: without his willingness to work weekends and middle-of-the-nights on my behalf, this project would be less coherent and less done. And it was H. Andrew Michener at the University of Wisconsin who made the essential connection between men's language of productivity and the everyday constructions of their sexuality, invaluable to my larger understandings of the relations between profit, class inequality, and masculinity.

Later versions profited from the efforts and attention of Mary Gatta at the Center for Women and Work at Rutgers University, Herman Benson at the Association for Union Democracy, Fran Benson at Cornell University Press, and two anonymous reviewers. Portions of the book also received valuable feedback from members of the Construction Economics Research Network (a project of the Center to Protect Workers' Rights and the National Institutes of Occupational Safety and Health), among whom Dale 
Belman of Michigan State University deserves a particular thank you for his support and assistance.

An earlier version of chapter 6 was previously published as "'Voluntarily Put Themselves in Harm's Way': The Bait-and-Switch of Safety Training in the Construction Industry," in Sociology of Job Training, Research in the Sociology of Work, Vol. 12 (Oxford, UK: Elsevier, 2003). The editor of that volume, David Bills, provided valuable feedback to drafts of that manuscript, as did two anonymous reviewers.

As a construction worker, a scholar, and a person, I have often been blessed with professional and personal support. Emily Kane, now of Bates College, provided the intellectual foundation for most of the questions I ask in this and other projects. I am grateful to Linda Goldenhar for her mentoring in safety research and the use of her focus group data. Eduardo Bonilla-Silva and Michael Kimmel have been profound role models and gracious advisers. Mary Gatta and Eileen Appelbaum at the Center for Women and Work at Rutgers University have my boundless gratitude for creating an institution in which outspoken women are celebrated and promoted. I particularly thank Jerry Marwell, an advisor without whom this project would not have been possible. He has been very tolerant of my need to find my own path intellectually and personally and provided some of the best pieces of advice and instruction that I continue to share with my students.

At the SUNY Institute of Technology, where I have been able to find some time and space to complete the manuscript, particular thanks go to Linda Weber, Maureen Helmer Cool, Bob Jones and Renee Jones in the print shop, Ron Foster (the librarian who can locate anything), and Ronni (a/k/a "Ronald") Tichenor (invaluable colleague and friend, a delightful motivator and competitor, and a source of sanity when it was otherwise hard to find).

Almost last but certainly not least, I have benefited tremendously from a family that has been willing to release me from family obligations in order to work on this project. Thank you, David, Ian, and Avery; and thank you, Bill and Penny. From a distance, my sister, Kim, and my dad, Tony, provided support and legal information. Jo, my stepmom, provided endless encouragement and buoyancy, and my mom, Sandy, has given me many things-among them the assumption that women can do anything and have the right to do so. Without that, I would be a different person and there would be no book. Additionally, Ken LeBlond created much needed momentum early on and his faith in me is the foundation of this.

Finally, it would be egregious for me to end these acknowledgments without addressing the men and women in the building trades who have 
made this book possible: the apprentices and instructors who pushed me along and treated me with respect (and often with humor); the foremen and co-workers who shared their tools and their tricks; everybody at Family Builders; the white women and people of color who created the path on which I was able to enter the industry; and a special thanks to the tradeswomen's support group and Nancy N., its guide, with whom I started my construction career. Thank you all. 



\section{WORKING GOMSTRUGTION}


